\title{
Influence of Personal and Task Interdependence on Task Conflict and Team Effectiveness
}

\author{
Jeffrey Lawrence D'Silva ${ }^{1}$, Adriana Ortega ${ }^{1} \&$ Abdul Hadi Sulaiman ${ }^{1}$ \\ ${ }^{1}$ Institute for Social Science Studies, Universiti Putra Malaysia, 43400 UPM Serdang, Selangor, Malaysia \\ Correspondence: Jeffrey Lawrence D'Silva, Institute for Social Science Studies, Universiti Putra Malaysia, \\ 43400 UPM Serdang, Selangor, Malaysia. Tel: 60389471862. E-mail: jld@upm.edu.my
}

Received: September 12, 2015

Accepted: December 29, 2015 Online Published: February 2, 2015

doi:10.5539/mas.v10n4p95

URL: http://dx.doi.org/10.5539/mas.v10n4p95

The research is financed by UPM Research Management Centre.

\begin{abstract}
Undeniably working in teams are important as tasks are getting more complicated and advanced as a result of globalization and the speedy growth of information and communication technology. This calls for effectiveness from team members to complete all interdependent sub-tasks to ensure that the given tasks achieve its' desired objectives. During the process of implementing the tasks, teams are poised to face conflicts that may derail the completion of tasks. The focus of this paper is to examine the influence of personality factors and task interdependence on task conflict and team effectiveness. A meta-analysis on past studies was carried out to gather data on the subject matter. The input obtained will be pertinent for future researchers in further understanding the complexities associated with task interdependence and personality on task conflict and team effectiveness.
\end{abstract}

Keywords: team effectiveness, task conflict, task interdependence, personality

\section{Introduction}

In most organizations, team based work assignments are increasingly common (Allen \& Hecht, 2004; Orsburn \& Moran, 2000). Evidence from several research works suggest that teams produce improved performance outcomes compared to working alone, particularly for problem-solving, decision making, and concept mastery tasks (Gigone \& Hastie, 1997). This performance advantage arises from the collaborations created through the mutual interdependence of team members (Allen \& Hetcht, 2004). However, there are significant constraints in working effectively as a team and in achieving effective performance. As noted by De Dreu and Weingart (2003), a key challenge for teams is resolving conflicts, in which tension often arises between team members as a result of personal or perceived differences (De Dreu, Harinck, \& Van Vianen, 1999).

This review seeks to build on previous research that investigated various facets of personal and task interdependence variables that play a key role in articulating a comprehensive perception of team performance. Attention will be drawn on a contingent view of the team conflict-performance relationship and then consider the inherent personal and task interdependence parameters involved in conflict management in teams. The initial understanding is illustrated in Figure 1.

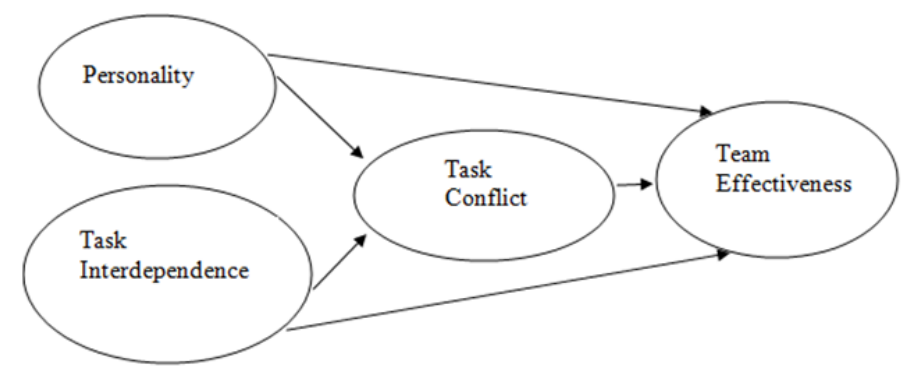

Figure 1. Influence of Personality and Task Interdependence on Task Conflict and Team Effectiveness 
Although personality conflicts may interfere with task performance, conflict about the best way to perform the task may lead to insights that increase task performance (Jehn et al., 1999). Therefore there is a need to investigate the relationship between personal and task-conflict interdependence to see how this influence task-conflict and team performance. In light of these issues, it is pertinent to investigate the fundamental determinants that affect a team's effectiveness. This will help to create and develop a more complex conceptualization and model framework of the nature of personal and task interdependence in understanding task-conflict and team effectiveness.

This paper will strive to show how personal and task differentially influences the relationship between conflict and decision making performance in teams. The major aim is to review team level literatures that explain how team members' personal behaviors differentially influence task conflict and decision making performance.

\section{Team Effectiveness}

There are various definitions of the term 'team' (Hackman \& Oldham, 1976; Smith et al., 1994; Tavana et al., 2013; Navarra \& Bibliotecas, 2010), however, Ayoko and Callan (2010) refers to team as a set of independent parties usually small in number who recognize themselves as a team, have some degree of shared accountability and who are collectively in charge of the achievement of one or several tasks as defined by the organization. The term team can also be referred to as a group of people with a full set of complementary skills required to complete a task. Teams become increasingly prevalent within educational and organizational settings (Gabelica et al., 2012). In general, team members work with a high sense of interdependence, share expertise and responsibility for the execution of a given task. They are accountable for the collective performance, and work toward a common goal usually assigned by their organization. As previously observed by Lewi and Slem (1995), in a work, the members share a common goal and are coordinated by a leader, but their performance is a function of individual effort which is evaluated by individual performance evaluations. Team work is increasingly becoming a fundamental issue in most organizations in their development programs (Levi \& Slem, 1995). The issue of team work gains prominence as a result of the increasing pressure on organizations to perform their tasks with more quality and effective results. This is particularly obvious in research and development organizations such as universities and institutions, where the complexity and diversity of their research teams makes team work a necessity.

In general, successful team work depends on the nature of synergism that exists between all team members (Tarricone \& Luca, 2001). This helps to create an environment where all team members are willing to contribute and participate towards promoting and nurturing an effective team environment. Team effectiveness requires the members demonstrate a sense of flexibility in the execution of their tasks through collaborative and interdependence (Luca \& Tarricone, 2001). Researchers have identified numerous attributes required for effective teamwork. These attributes are commitment to team success and shared goals, interdependence, interpersonal skills, open communication and positive feedback and appropriate team composition. Although team leader tends to select team members he or she deems appropriate for the job, the personal opinions of team members are often not considered in the team formation process (Wang \& Zhang, 2015).

\section{Task Conflict in Teams}

Task conflict is referred to as the disagreement among group members about decisions, viewpoints, ideas, and opinions (Simons \& Peterson, 2000) and as potentially including controversy over the best way to achieve a group goal or objective (Devine, 1999). Among the interpersonal processes that operate in teams, one of the most studied is team conflict (Mathieu et al., 2008). There is a general consensus in the literature that task conflict is an important predictor of team performance (Puck \& Pregernig, 2014), although the, the question of how and why it influences performance is still not fully comprehended. Although conflict in teams and organizations is virtually unavoidable (Jehn, 1995), scholars have found conflict to be both harmful and beneficial to team performance (Troth, 2009). For example, conflict may cause reduced productivity and satisfaction in teams (Wall \& Nolan, 1986), studies by Chatman (2000) showed that organizations, where functional conflict is part of the culture within teams, can improve decision quality as different ideas are expressed and resolved openly (Jehn and Chatman, 2000). Team conflict is multidimensional, consisting of both relationship- and task-based elements (Jehn \& Bendersky, 2003; Korsgaard et al., 2008). The current consensus is that the relationship between team conflict and team performance outcomes depends significantly on factors such as the nature of conflict and the type of the task, the interdependence of the team, and team norms about conflict (Jehn, 1995).

Team conflict may refer to divergence in views and squabbling due to personal mismatch, which typically result in tension, annoyance and acrimony among team members within a group (Jehn, 1995). Furthermore, task-related conflict may involve personal issues such as contrasting opinions, viewpoints, feelings, ideas and 
emotions that may the progress of the task at hand (Parayitam \& Dooley, 2009). It is commonly believed that an individual's characteristics during task performance is influenced by factors such as team conflict norms, individual characteristics, work structure, team characteristics, task characteristics and the interaction among these input characteristics. The conceptual framework of these parameters will greatly influence each other, as previously reported by Yang and Mossholder (2004), Ashkanasy and Daus (2002), Bodtker and Jameson (2001), which suggest the connection between work place conflict and emotions.

It appears that scholars' have contrasting views about the consequences of task conflicts, where some reported that it is beneficial for organizations and can assist in stimulating organizational performance (Tjosvold, 1991; Jehn, 1994), while others such as De Dreu and Weingart (2003) suggested that conflict has a more damaging impact on team performance. In general, individuals' reactions to conflict differ considerably (Bennet \& Savani, 2004; Jehn \& Chatman, 2000). Bennet and Savani (2004) reported that individuals may react to conflict with sulkiness, resentfulness or withdrawal, while others may retort to compromise and accommodation (McKenna \& Richardson, 1995). It is important to note that the differing perceptions of conflict by team members may explain the varying reactions difference in perception (Ayoko \& Callan, 2010) and this may trigger a negative influence on the team's performance. A recent study by Amanuel and Nzarda (2014) shows that the team members on teams that are have similar characteristics such as agreeableness, conscientiousness, and emotional stability are more likely to cope with relationship conflict, thus preventing conflict from negatively influencing their work. In any case, the issue of whether conflict is good or bad for team performance seems to depend on the type of conflict (De Wit et al., 2012). Given the negative implications of task conflict, avoiding conflict in general might be a good option (Puck \& Pregernig, 2014), although other studies suggested that avoiding conflict evokes feelings of injustice and leads to team ineffectiveness (Shaw et al., 2011).

\section{Influence of Task Interdependence on Task Conflict and Team Effectiveness}

The occurrence of conflict has been identified to interfere with team performance due to the fact that it leads to tension, antagonism, and distraction among team members from performing their assigned tasks. Examples of task conflict are conflicts about the distribution of resources, procedures and policies, and judgments and interpretation of facts (De Dreu \& Weingart, 2003). Relationship conflict is an important interpersonal stressor associated with team work (Ilies et al., 2011; Pluut et al., 2013) and is observed to reduce teamwork quality (Chen et al., 2011).

A recent research by Bradley et al. (2012) using evidence from 117 research project teams, suggest that task conflict and team performance were positively associated under conditions of high psychological safety climate. Research efforts on conflict in teams suggested 'task conflict' and 'relationship conflict' as the two common forms of conflict that exist (Jehn, 1995). The task-related conflicts emanates from the existence of disagreements among team members about the content of the tasks being performed, including differences in viewpoints, ideas, and opinions (Troth, 2009). In contrast, relationship conflict encompasses apparent tension and frustration about personal differences such as attitudes and preferences, interpersonal style and personality (De Dreu and Weingart, 2003; Jehn, 1997). Team effectiveness may not only be influenced by task characteristics, but also by factors, such as team formation, team members' abilities and characteristics, role assignment within a team, decision making strategies of teams, team leadership, and interdependency (Fransen et al., 2011).

A recent study by Lee et al. (2014) explains the key factors that influence the job performance of real estate brokers. The findings revealed that task conflict and relationship conflict were positively and significantly influenced by team diversity. The work further showed that teams that are highly diverse in terms of member composition may lead to differences in opinion, task conflict, and relationship conflict. The findings further imply that task interdependence influences relationship conflict, team cooperation and performance.

\section{Influence of Personality Factors on Task Conflict and Team Effectiveness}

Personality refers to a stable set of characteristics that are responsible for a person's identity and the internal dimension of diversity are strongly influence our attitudes, expectations and assumptions about others, thus influencing our behavior (Kinicki, 2008). Likewise, Colquitt (2009) defines personality traits as the propensities inside a person that explains his or her characteristic patterns of thought, emotion and behavior. Personality traits can influence task conflict and overall team performance. Ineffective teams may be the product of inappropriate team composition. Colquitt (2009) further identified five dimensions that describe personality, these include; conscientiousness, agreeableness, neuroticism, openness to experience and extraversion commonly referred to as the big five.

Research by Bradley et al. (2013) indicated that personality factors such as openness to experience and emotional stability function as moderators of the relationship between task conflict and team performance. The 
findings further revealed that specifically, task conflict exhibited a positive impact on performance in teams with high levels of openness or emotional stability; in contrast with those that showed a negative impact on performance in teams with low levels of openness or emotional stability. The ultimate success of teams is not only confined to the members' talents and resources, but also the interactive nature of team members, which are strongly, determined by the characteristics of the individual team members. The personality differences play a vital role in the success of any given team. Some of the personality differences are easily noticeable like gender, age, ethnicity, while others such as attitudes, values, character are less readily observable. Personality factors are extremely important in task conflict management and team effectiveness in today's competitive organizational settings.

\section{Conclusion}

The issue of why some teams attain success in their respective tasks, while others fail prompts the need to identify the essential attributes needed for successful teamwork performance in an organization. This review highlights important information on the interactive effect of personal and task interdependence in task-conflict and team performance in organizations to help address the issue of conflict management in group tasks. Most studies identified diversity and personality factors as highly pertinent in task conflict management, and effective team performance. It is important to further investigate the impacts of various types of conflict on the team members' reactions to conflict on team outcomes. Team members have meaningful roles to play in achieving team goals. There is the need to understand and recognize the significant role that team leaders have in the management of conflicts in teams.

\section{References}

Allen, N. J., \& Hecht, T. D. (2004). The "romance of teams": Toward an understanding of its psychological underpinnings and implications. Journal of Occupational and Organizational Psychology, 77, 439-462.

Amanuel, G. T., \& Narda, R. (2014). Quigley, Team deep-level diversity, relationship conflict, and team members' affective reactions: A cross-level investigation. Journal of Business Research, 66(3), 394-402.

Ashkanasy, N. M., \& Daus, S. D. (2002). Emotion in the workplace: The new challenge for managers. Academy of Management Executive, 16, 76-86.

Ayoko, O. B., \& Callan, V. J. (2010). Teams reactions to conflict and teams' task and social outcomes: The moderating role of transformational and emotional leadership. European Management Journal, 28, 220 235.

Bennet, R., \& Savani, S. (2004). Managing conflict between marketing and other functions within charitable organizations. Leadership and Organizational Development Journal, 25(2), 180-200.

Bodtker, A. M., \& Jameson, J. K. (2001). Emotion in conflict formation and its transformation: Application to organizational management. International Journal of Conflict Management, 22, 259-275.

Bradley, B. H., Klotz, A. C., Postlethwaite, B. E., \& Brown, K. G. (2013). Ready to rumble: How team personality composition and task conflict interact to improve performance. Journal of Applied Psychology, 98(2), 385-392.

Bradley, B. H., Postlethwaite, B. E., Klotz, A. C., Hamdani, M. R., \& Brown, K. G. (2012). Reaping the Benefits of Task Conflict in Teams: The Critical Role of Team Psychological Safety Climate. Journal of Applied Psychology, 97(1), 151-158.

Chen, G., Sharma, P. N., Edinger, S. K., Shapiro, D. L., \& Far, J. L. (2011). Motivating and demotivating forces in teams: cross-level influences of empowering leadership and relationship conflict. Journal of Applied Psychology, 96, 541-557.

Colquitt, J., Le Pine, J., \& Wesson, M. (2009). Organizational Behavior; improving performance and commitment in the workplace. New York, McGraw-Hill, Irwin

De Dreu, C. K. W, Harinck, F., \& Van Vianen, A. E. M. (1999). Conflict and performance in groups and organizations', in CL Cooper \& IT Robertson (eds.), International Review of Industrial and Organizational Psychology, 14, 376-405.

De Dreu, C. K. W., \& Weingart, L. (2003). Task versus relationship conflict, team performance, and team member satisfaction: A meta-analysis. Journal of Applied Psychology, 88, 741-749.

De Wit, F. R. C., Greer, L. L., \& Jehn, K. A. (2012). The paradox of intragroup conflict: A meta-analysis. Journal of Applied Psychology, 97, 360-390. 
Devine, D. J. (1999). Effects of cognitive ability, task knowledge, information sharing, and conflict on group decision-making effectiveness. Small Group Research, 30, 608-634.

Fransen, J., Kirschner, P. A., \& Erkens, G. (2011). Mediating team effectiveness in the context of collaborative learning: The importance of team and task awareness. Computers in Human Behavior, 27(3), 1103-1113.

Gabelica, C., Bossche, P. V., Segers, M., \& Gijselaers, W. (2012). Feedback, a powerful lever in teams: A review. Educational Research Review, 7(2), 123-144.

Gigone, D., \& Hastie, R. (1997). Proper analysis of the accuracy of group judgments. Psychological Bulletin, 121, 149-167.

Hackman, J. R., \& Oldham, G. R. (1976). Motivation through the design of work: Test of a theory. Organizational Behavior and Human Performance, 16, 250-279.

Ilies, R., Johnson, M. D., Judge, T. A., Keeney, J. (2011). A within-individual study of interpersonal conflict as a work stressor: Dispositional and situational moderators. Organ Behav, 32, 44-64.

Jehn, K. (1997). A qualitative analysis of conflict types and dimensions in organizational groups. Administrative Science Quarterly, 42, 530-557.

Jehn, K. (1995). A multimethod examination of the benefits and detriments of intra-group conflict', Administrative Science Quarterly, 40, 256-282.

Jehn, K. A. (1994). Enhancing effectiveness: An investigation of advantages and disadvantages of value-based intragroup conflict. International Journal of Conflict Management, 4, 223-238.

Jehn, K. A., \& Chatman, J. A. (2000). The influence of proportional and perceptual conflict composition on team performance', International Journal of Conflict Management, 11, 56-73.

Jehn, K. A., Northcraft, G. B., \& Neale, M. A. (1999). Why Differences Make a Difference: A Field Study of Diversity, Conflict, and Performance in Workgroups Administrative Science Quarterly, 44(4), 741-763.

Jehn, K. A., \& Bendersky, C. (2003). Intragroup conflict in organizations: A contingency perspective on the conflict-outcome relationship. Research in Organizational Behavior, 25, 187-242.

Kinicki. (2008). Organizational Behavior: Core Concepts. New York, McGraw-Hill Irwin.

Korsgaard, M. A., Jeong, S. S., Mahony, D. M., \& Pitariu, A. H. (2008). A multilevel view of intragroup conflict. Journal of Management, 34, 1222-1252.

Lee, C., Lee, Y., Chen, H., Hsieh, P., Yeh, Y., \& Lin, M. (2014). The impact of team diversity, task interdependence, team conflict and team cooperation on job performance: using real estate brokers as examples. 2014. International Journal of Management and Sustainability, 3(7), 415-432.

Levi, D., \& Slem, C. (1995). Team work in research and development organizations: The Characteristics of successful teams. International Journal of Industrial Ergonomics, 16, 29-42.

Mathieu, J., Maynard, M. T., Rapp, T., \& Gilson, L. (2008). Team effectiveness 1997-2007: A review of recent advancements and a glimpse into the future. Journal of Management, 34, 410-476.

McKenna, S., \& Richardson, J. (1995). Business values, management and conflict handling: Issues in contemporary Singapore. Journal of Management Development, 14(4), 56-70.

Navarra, U. D., \& Bibliotecas, E. (2010). Team formation and self-serving biases. Journal of Economic Management Strategy, 19, 117-135.

Orsburn, J. D., \& Moran, L. (2000). The new self-directed work teams: Mastering the challenge (2nd edn.), McGraw-Hill, New York.

Parayitam, S., \& Dooley, R. S. (2009). The interplay between cognitive- and affective conflict and cognitionand affect-based trust in influencing decision outcomes. Journal of Business Research, 62, 789-796.

Pluut, H, \& CurŞeu, P. L. (2013). Perceptions of intragroup conflict: The effect of coping strategies on conflict transformation and escalation. Group Process Intergroup Relat, 16, 412-425.

Puck, J., \& Pregernig, U. (2014). The effect of task conflict and cooperation on performance of teams: Are the results similar for different task types? European Management Journal, 32(6), 870-878.

Shaw, J. D., Zhu, J., Duffy, M. K., Scott, K. L., Shih, H. A., \& Susanto, E. (2011). A contingency model of conflict and team effectiveness. Journal of Applied Psychology, 96, 391-400. 
Simons, T. L., \& Peterson, R. S. (2000). Task conflict and relationship conflict in top management teams: The pivotal role of intragroup trust. Journal of Applied Psychology, 85, 102-111.

Smith, K., Smith, K., Olian, J., Sim, H., Banno, D., \& Scully, J. (1994). Top management team demography and process: The role of social integration and communication. Administrative Science Quarterly, 39, 412-438.

Tarricone, P., \& Luca, J. (2002). Successful teamwork: A case study. HERDSA, 640.

Tavana, M., Azizi, F., Azizi, F., \& Behzadian, M. (2013). A fuzzy inference system with application to player selection and team formation in multi-player sports. Sport Management Review, 16, 97-110.

Tjosvold, D. (1991). The conflict-positive organization: Stimulate diversity and create unity. Addison-Wesley, Reading, MA.

Troth, A. (2009). A model of team emotional intelligence, conflict, task complexity and decision making. International Journal of Organisational Behaviour, 14(1), 26-40.

Wall, V., \& Nolan, L. (1986). Perceptions of inequity, satisfaction, and conflict in task oriented groups. Human Relations, 39, 1033-1052.

Wang, J., \& Zhang, J. (2015). A win-win team formation problem based on the negotiation. Engineering Applications of Artificial Intelligence, 44, 137-152.

Yang, J. X., \& Mossholder, K. W. (2004). Decoupling task and relationship conflict: The role of intra-group emotional processing. Journal of Organizational Behavior, 25, 589-605.

\section{Copyrights}

Copyright for this article is retained by the author(s), with first publication rights granted to the journal.

This is an open-access article distributed under the terms and conditions of the Creative Commons Attribution license (http://creativecommons.org/licenses/by/3.0/). 